\title{
Communication
}

[Comunicação]

\section{Use of the cryostat to prepare slides for trichological analysis}

[Uso do aparelho criostato para preparação de lâminas para a análise tricológica]

\author{
G.A. Felix', M.C.S. Fioravanti ${ }^{2}$, J.S. Garbelini ${ }^{3}$, R.S. Juliano ${ }^{4}$, \\ A.A.B. Sobrinho ${ }^{4}$, U. Piovezan ${ }^{5}$
}

\author{
${ }^{1}$ Faculdade de Medicina Veterinária - Centro Universitário Grande Dourados - Dourados, MS \\ ${ }^{2}$ Faculdade de Medicina Veterinária e Zootecnia - Universidade Federal de Goiás - Goiânia, GO \\ ${ }^{3}$ Fundação do Meio Ambiente do Pantanal - Corumbá, MS \\ ${ }^{4}$ Embrapa Pantanal - Corumbá, MS \\ ${ }^{5}$ Embrapa Tabuleiros Costeiros, Aracaju, SE
}

The analysis of the morphological and morphometric patterns of mammalian hair microstructures constitutes a valuable noninvasive technique for the identification of mammalian species. This type of analysis is widely used in taxonomic, ecological, paleontological, and archaeological research, as well as in food quality control and forensic investigation (Quadros and Monteiro-Filho, 1998) and animal production (Felix et al. 2019).

The microstructure of the mammalian hair encompasses three concentric layers of keratinized cells (Teerink, 1991; Quadros and Monteiro-Filho, 2006). The outermost layer is the cuticle, the intermediate is the cortex, and the innermost layer, the marrow (Teerink, 1991). The cortex is formed by hard $\alpha$-keratin deposits, which also form the cuticle, although the cells of this layer may also contain melanin granules (Quadros and Monteiro-Filho, 2006). The cortex is composed of spindle-shaped, non-nucleated cells arranged concentrically and filled with rigid $\alpha$ keratin, which cannot be observed by transmission or reflection in optical microscopy (Keogh, 1983), but can be detected in scanning electron microscopy (Hausman, 1920).

The structure of the cortical layers of the hair, the medullary pattern, and the cuticular arrangement all vary considerably among taxa, and can be used for the morphological and morphometric identification of species (Chernova, 2003). In fact, the unique combination of the principal characteristics of the cuticle, marrow and cortex of the guard hairs can be used to establish keys for identification of mammalian species (Teerink, 1991; Chernova, 2003; Quadros and MonteiroFilho 2010; Felix et al., 2019). Mammalian hairs can be divided into two types, the guard hairs (Figure 1) and the undercoat. The hairs of the undercoat are shorter, thinner, wavier, and more densely packed than the guard hairs, and have both thermoregulation and water repellant functions (Vanstreels et al., 2010; Felix et al., 2014). The guard hairs are longer, thicker, and less numerous, tend to be salient, and contributes primarily to mechanoreception, camouflage, and the general pattern of coat coloration (Teerink, 1991).

The guard hairs can be further subdivided into primary and secondary hairs, with two main components, the shaft and the shield (Figure 1). The shaft is the portion of the hair that grows out of the bulb, and is relatively narrow and straight, while the shield is broader, and forms the distal extremity of the hair (Quadros and MonteiroFilho, 2006; Felix et al., 2014). The cuticular characteristics of the shaft, and the medullary and cortical traits of the shield of guard hairs provide fundamental criteria for the diagnosis of species (Teerink, 1991; Felix et al., 2019). It is thus essential to ensure that the hairs being collected for the trichological analysis are guard hairs rather than undercoat hairs. 


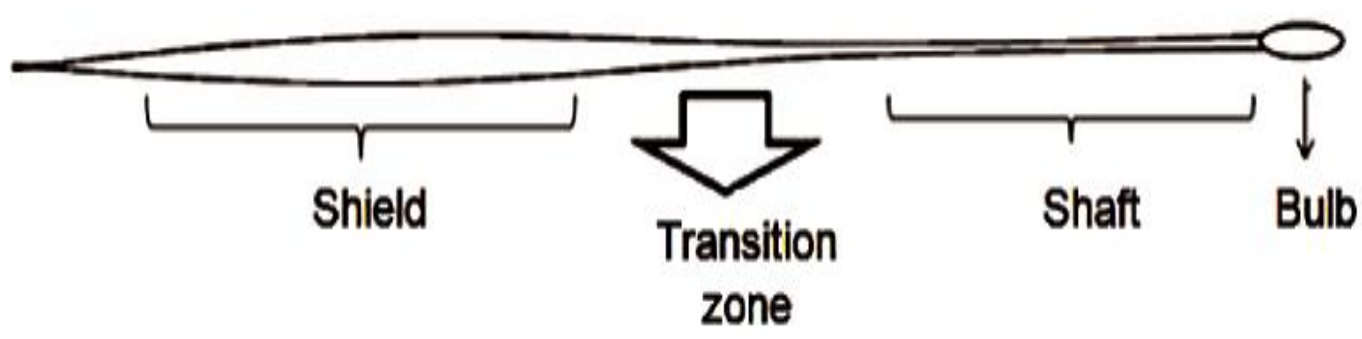

Figure 1. Schematic diagram of the structure of a mammalian guard hair (from: Felix et al., 2014).

Neither the hair follicle nor the cortex is important for species identification, although the size of the cortex relative to the marrow can be a useful criterion. Despite its limitations, some authors have used this microstructure as part of a species diagnosis. For example, Chernova et al. (2016) included genetic, trichological, and isotopic analyses of Cave Lion (Panthera spelaea, Goldfuss, 1810) hairs, analyzing the medullary, cuticular, and cortex patterns to identify the species. Cross-sections of the hairs were obtained using a sharp razor blade, to expose the cortex. Fattorini et al. (2018) were able to distinguish hairs from four species of hare (Lepus corsicanus, Lepus timidus, Lepus capensis, and Lepus europaeus) based on the protocol described by Mori et al. (2016), who used the medullary and cuticular patterns to identify gray squirrels (Sciurus carolinensis) in the Italian regions of Tuscany and Veneto. Neither of these studies described how the hairs were sectioned to expose the medullary cortex.

Most trichological studies of mammalian species or breeds have been based on established protocols for the medullary and cuticular analysis of hairs (Teerink, 1991; Quadros \& MonteiroFilho, 2010; Sato et al., 2010; Felix et al., 2019), rather than the cortex, which requires the more complex procedure of the cross-sectioning of the hair. To overcome this limitation, the present study describes a new approach, based on the use of a cryostat, for the acquisition of hair crosssections that expose the cortex of mammalian guard hairs for analysis.

\section{MATERIALS AND METHODS}

We used samples obtained from the scapular (dorsal) region of the study animals, in which the undercoat is less dense. While samples taken directly from the animal are ideal, they can also be obtained from other sources, including fecal or gastrointestinal samples, regurgitant or even from archeological specimens. Subsamples of the guard hairs are obtained for each individual analyzed. Hairs with the bulb and its extremity still attached should be selected for analysis and are then washed in commercial alcohol and neutral detergent. A magnetic stirrer can be used to wash the hairs. Once washed, the hairs are dried using absorbent paper.

The present study used samples of guard hairs obtained from the Brazilian Pantaneiro cattle breed (Bos taurus taurus). The hairs were micro dissected for the analysis of the cortex at the Embrapa Pantanal trichology laboratory (with permission from the Animal Ethics Commission CEUA/Embrapa Pantanal - CPAP 012_2016). The samples were selected from 10 animals, with 10 replicates. The successful identification of a species or breed depends on the availability of a sample of adequate size, and the morphological and morphometric analysis of all three concentric layers of the hair (Felix et al.; 2019).

As the medullary cortex is analyzed only in the shield region of the hair, it is recommendable to remove the shaft with a surgical blade (under a stereoscopic binocular microscope) prior to placing the hairs in the cryostat. For analysis, a number of clean, dry, and shaftless hairs are placed in the cryostat holder, submerged in Tissue Freezing Medium ${ }^{\circledR}$, a highly viscous and watersoluble compound of glycols, which solidifies at temperatures of $-10^{\circ} \mathrm{C}$ or less, permitting the acquisition of the cross-sections. A Leica CM 1520 (Leica Inst., Nussloch, Germany) cryostat was used for the processing of the samples. 


\section{Use of the cryostat...}

\section{RESULTS}

Processing in the cryostat permitted the acquisition of hair sections $7.0 \mu \mathrm{m}$ thick. It is important to note that the exact thickness of the sections should be modified according to the diameter of the hair samples. The cryostat must be maintained at a temperature of $-30^{\circ} \mathrm{C}$ in order to obtain the sections. Subsequently, the tapes containing the hair sections (Figure 2) were placed on a glass microscopic slide and covered with a coverslip to determine which sections were adequate for the analysis of the hair cortex, based on the criteria of Teerink (1991).

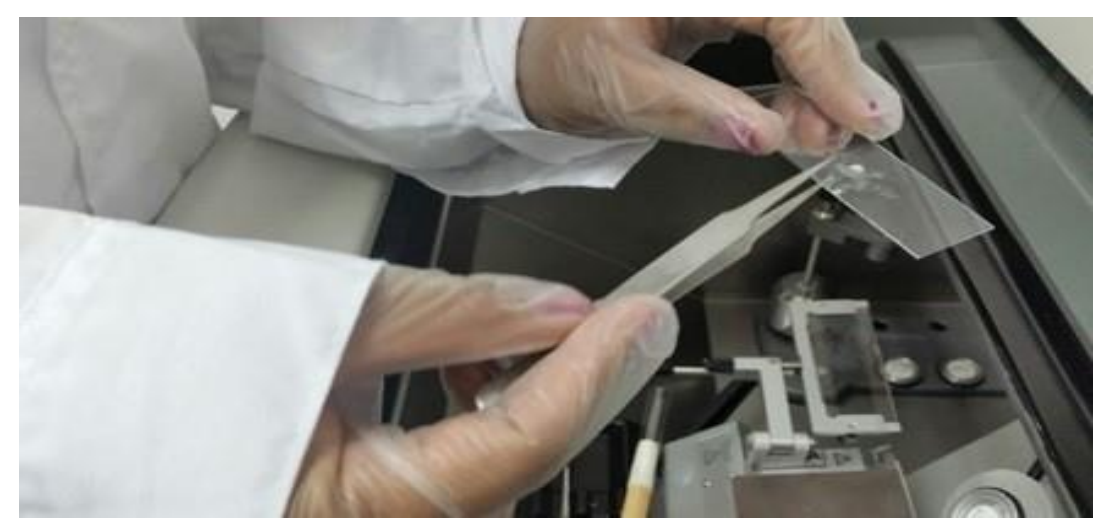

Figure 2. Removing tapes from the Leica CM 1520 cryostat for the preparation of slides for viewing the cortex by optical microscopy.

To confirm the quality of the processing, preliminary slides were prepared with water for optical microscopy (Nikon Eclipse E200), with a $10.0 \mathrm{x}$ eyepiece, 20.0 and $40.0 \mathrm{x}$ objective lenses, and transmitted light without filtering. The sections obtained in the cryostat will be cut in different shapes and directions. Given this, it is necessary to evaluate a number of different slides to ensure that an adequate crosse-section has been obtained. After determining which sections provided the best image of the medullary cortex, permanent slides were made using cedar oil and coverslips. These slides were analyzed by optical microscopy, with a $10.0 \mathrm{x}$ eyepiece, 20.0 and 40.0 $\mathrm{x}$ lenses, and transmitted light without filtering, for the visualization of the entire section of the cortex.

High resolution (2048 x 1536 pixels resolution) images are recommended for the most reliable analysis of the hair sections. In the present study, the images were obtained using a digital camera equipped with Motic Images Plus® 2.0 ML image-capture software (Figure 3).

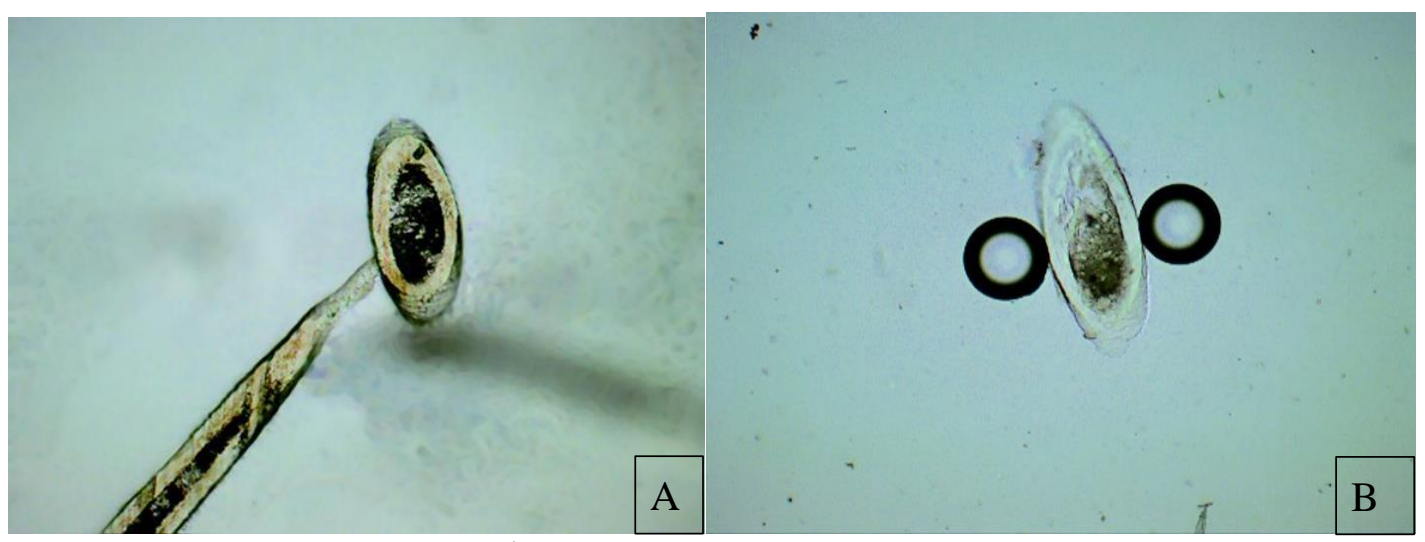

Figure 3. A- Cross Section $7.0 \mu \mathrm{m} /$ optical microscopy, with a 40.0 x lenses. B- Cross Section $7.0 \mu \mathrm{m} /$ optical microscopy, with a $40.0 \mathrm{x}$ lenses Cross section of Pantaneiro cattle breed guard hair, made with Leica CM 1520 cryostat, allowing visualization of the medullary cortex (red arrow). 
The analysis of the hair cortex is rarely used for the diagnosis of mammalian species, given that the techniques used to obtain the data on this feature of the hair are often difficult to replicate. Crump and Danks (1971) demonstrated a simple method for the acquisition of transverse hair sections using razor blades. This technique was adapted from the approach used by Ford and Simmens (1959). Despite being a low-cost approach, this technique is not easy to apply, even to relatively thick hairs, such as those of pigs (Sus scrofa), and is practically impossible for finer hairs such as those of cattle, which were analyzed in the present study.

This technical paper describes an easily replicable method for the analysis of the medullary cortex of mammalian guard hairs. The proposed method addresses a fundamental methodological problem for trichological analyses and permits the acquisition of cross sections that expose the cortex of the hair for analysis, thus increasing the potential of trichological analyses for a more reliable identification of mammal species.

Keywords: animal forensic science, microscopic hair identification, noninvasive procedures, trichology

\section{RESUMO}

A análise dos padrões morfológicos e morfométricos das microestruturas capilares é uma técnica não invasiva que pode ser utilizada para identificar espécies de mamíferos. Esta técnica pode ser aplicada em diversas áreas da ciência animal, tais como controle de qualidade de alimentos e análises forenses. Dada a dificuldade de obter seções transversais de pelos de guarda para expor o córtex, a maioria dos estudos analisou apenas os componentes medulares e cuticulares do pelo. A inclusão do córtex capilar de guarda em uma análise tricológica pode proporcionar uma descrição mais precisa das raças ou espécies de mamíferos. O presente estudo propõe um novo método para a execução de cortes transversais que expõem o córtex do pelo guarda de mamíferos utilizando um criostato.

Palavras-chave: ciência forense animal, identificação microscópica do pelo, procedimentos não-invasivos, tricologia

\section{ACKNOWLEDGMENTS}

This study was financed by the National Council for Scientific and Technological Development (CNPq) and Rede Pró-Centro Oeste.

\section{REFERENCES}

CHERNOVA, O.F. Architectonic and diagnostic significance of hair cortex and medulla. Biol. Bull., v.30, p.53-62, 2003.

CHERNOVA, O.F.; KIRILLOVA, I.V.; SHAPIRO, B. et al. Morphological and genetic identification and isotopic study of the hair of a cave lion (Panthera spelaea Goldfuss, 1810) from the Malyi Anyui River (Chukotka, Russia). Quat. Sci. Rev., v.142, p.61-73, 2016.

CRUMP, I.; DANKS, D.M. Simple method for cutting transverse sections of hair. Arch. Dis. Child., v.46, p.383-386, 1971.
FATTORINI, N.; BURRINIA, L.; MORA, G. et al. Splitting hairs: how to tell hair of hares apart for predator diet studies. Mamm. Biol., v.89, p.8489, 2018.

FELIX, G.A.; FIORAVANTI, M.C.S.; CASSANDRO, M. et al. Bovine breeds identification by trichological analysis. Animals, v.9, p.761, 2019.

FELIX, GA, PIOVEZAN, U, QUADRO, S J, JULIANO, RS, ALVES, FV, FIORAVANTI, M.C.S. Thricology for identifying mammal species and breeds: its use in research and agriculture. Arch. Zootec., v.63, p.107-116, 2014.

FORD, J.E.; SIMMENS, S.C. Fibre section cutting by the plate method. J. Text. Inst., v.50, p.148, 1959.

HAUSMAN, L.A. Structural characteristics of the hair of mammals. Am. Midl. Nat., v54, p.496-523, 1920. 
KEOGH, H.J.A. photographic reference system of the microstructure of the hair of southern African bovids. S. Afr. J. Wildl. Res., v.13, p.89132, 1983.

MORI, E.; AMERINI, R.; MAZZA, G. et al. Alien shades of grey: new occurrences and relevant spread of Sciurus carolinensis in Italy. Eur. J. Ecol., v.2, p.13-20, 2016.

QUADROS, J.; MONTEIRO-FILHO, E.L.A. Identificação dos mamíferos de uma área de floresta atlântica utilizando a microestrutura de pelos-guarda de predadores e presas. Arq. Museu Nacl., v.68, p.47-66, 2010.

QUADROS, J.; MONTEIRO-FILHO, E.L.A. Effects of digestion, putrefaction and taxidermy processes on Didelphis albiventris hair morphology. J. Zool., v.224, p.331-334, 1998.
QUADROS, J.; MONTEIRO-FILHO, E.L.A. Revisão conceitual, padrões microestruturais e proposta nomenclatória para os pelos guarda de mamíferos brasileiros. Rev. Bras. Zool., v.23, p.279-296, 2006.

SATO, I.; NAKAKI, S.; MURATA, K.; TAKESHITA, H.; MUKAI, T. Forensic hair analysis to identify animal species on a case of pet animal abuse. Int. J. Legal Med., v.124, p.249256, 2010.

TEERINK, B.J. Hair of west European mammals: atlas and identification. Cambridge: Cambridge University Press. 1991. 224p.

VANSTREELS, R.E.T.; RAMALHO, F.P.; ADANIA, C.H. Microestrutura de pelos guarda de felídeos brasileiros:Considerações para a identificação de espécies. Biota Neotrop., v.10, p.333-337, 2010. 